\title{
Klasifikasi Jenis Tanaman Mangga Gadung dan Mangga Madu Berdasarkan Tulang Daun
}

\author{
Suastika Yulia Riska ${ }^{1}$, Laili Cahyani ${ }^{2}$, Muhammad Imron Rosadi ${ }^{3}$ \\ Program Studi Teknik Informatika, Fakultas Teknologi Informasi \\ Institut Teknologi Sepuluh Nopember \\ Kampus ITS Keputih, Sukolilo, Surabaya 60111, Jawa Timur \\ E-mail: ${ }^{1}$ riska.suastika13@mhs.if.its.ac.id, ${ }^{2}$ laili.cahyani13@mhs.if.its.ac.id, \\ 3imron_uyp@yahoo.com
}

Masuk: 7 Juni 2014; Direvisi: 20 Juni 2014; Diterima: 23 Juni 2014

\begin{abstract}
Leaf is an important part of plant that help classify the types of mango plants. An application of Unconstraint Hit or Miss Transformation (UHMT) with four structuring elements (SE) result in high computational complexity. Thus, this research aims to simplify the computational complexity by applying one of nine SE in UHMT. Vein pattern features obtained by applying Local Binary Pattern (LBP), then the results obtained features are calculated by entropy. The results show that the high average of entropy values are categorized as honey mango or locally known as madu mango.. Classification Tests to comparing the classification accuracy of the K-fold Cross Validationwith the values of $K$-fold are 5, 8, and 10. The highest accuracy is the use of 10-fold Cross Validition which reaches $78.5 \%$.
\end{abstract}

Keywords : classification, uhmt, structuring element, vein

\begin{abstract}
Abstrak. Daun merupakan salah satu bagian tanaman yang dapat menjadi acuan klasifikasi, karena memiliki perbedaan fitur pada setiap jenis mangga. Penerapan Unconstraint Hit or Miss Transformation (UHMT) dengan empat structuring element (SE) mengakibatkan tingginya kompleksitas komputasional. Sehingga, penelitian ini bertujuan untuk menyederhanakan kompleksitas komputasi dengan menerapkan satu dari sembilan SE pada UHMT. Pola fitur tulang daun diperoleh dengan menerapkan Local Binary Pattern (LBP), kemudian hasil fitur yang diperoleh dihitung dengan entropy. Hasil menunjukkan bahwa rata-rata nilai entropy yang tinggi dikategorikan pada mangga madu. Pengujian klasifikasi membandingkan akurasi pada K-fold Cross Validation, dengan nilai $K$-fold adalah 5, 8, dan 10. Akurasi tertinggi dengan menggunakan 10-fold Cross Validition yaitu 78,5\%.
\end{abstract}

Kata kunci : klasifikasi, uhmt, structuring element, tulang daun

\section{Pendahuluan}

Daun merupakan salah satu bagian tanaman yang sering digunakan untuk mengklasifikasikan jenis tanaman (Jabal, dkk, 2013). Daun digunakan untuk mengklasifikasikan tanaman, karena setiap jenis tanaman memiliki fitur daun yang berbeda (Fu \& Chi, 2006 dan Jabal, dkk, 2013). Selain itu, daun lebih mudah diperoleh karena tidak tergatung pada musim (Jabal, dkk, 2013).

Tanaman mangga merupakan tanaman buah yang potensial dikembangkan karena mempunyai tingkat keragaman genetik yang tinggi. Daun mangga memiliki variasi dalam hal bentuk, ukuran dan warna daun, yang menunjukkan keragaman genetik yang cukup luas. Perbedaan fitur daun setiap jenis tanaman menjadikan daun sebagai salah satu acuan untuk melakukan klasifikasi setiap jenis tanaman (Fu \& Chi, 2006). Struktur tulang daun sebagai salah satu fitur yang dapat membedakan daun dari berbagai jenis tanaman, karena tulang daun memiliki fitur yang unik pada setiap jenis tanaman. Penggolongan varietas mangga selama ini 
dilakukan secara manual, sehingga dibutuhkan suatu aplikasi yang dapat menggolongkan jenis mangga secara otomatis melalui serangkaian proses pengolahan citra daun mangga.

Pada beberapa penelitian sebelumnya telah dilakukan klasifikasi jenis tanaman berdasarkan fitur daun. Penelitian tersebut diantaranya melakukan klasifikasi dengan menggabungkan fitur bentuk, warna, dan tekstur daun mengunakan flactal measure (lacunarity) dan probabilistic neural network (PNN) (Kadir \& Susanto, 2011). Penelitian lainnya menggabungkan thresholding dan ANN untuk ekstraksi tulang daun (Fu \& Chi, 2006). Penelitian dalam hal ekstraksi daun juga dilakukan, yaitu dengan mengusulkan metode ekstraksi tulang daun berdasarkan morfologi gray-scale (Zheng \& Wang, 2010). Selain itu, telah diusulkan ekstraksi tulang daun menggunakan metode independent component Analysis (ICA) (Li \& Chi, 2006). Penelitian terkait klasifikasi berdasarkan daun dilakukan pada bunga kamelia (Lu, dkk, 2013). Penelitian tersebut menggunakan morfologi dan tulang daun untuk membedakan spesies bunga kamelia. Pengujian dilakukan dengan membandingkan tiga metode klasifikasi, yaitu kombinasi learning vector quantization dan artificial neural network (LVQANN), dynamic architecture for artificial neural networks (DAN2), dan support vector machines (SVM). Sehingga, metode klasifikasi yang menunjukkan tingkat akurasi tinggi adalah DAN2 dan SVM. Selain itu, klasifikasi tanaman berdasarkan fitur tekstur dari daun dengan menggunakan kombinasi LVQ dan radial base function (RBF) juga telah dilakukan (Rashad, Desouky \& Khawasik, 2011).

Penelitian tentang cara otomatis untuk melakukan pengenalan tanaman kacangkacangan berdasarkan fitur morfologi tulang daun telah diusulkan (Larese, dkk, 2013). Pada proses segmentasi daun, digunakan metode unconstrained hit or miss transform (UMHT) dengan menerapkan 4 structuring element dan adaptive thresholding. Metode klasifikasi yang digunakan yaitu dengan membandingkan antara support vector machines (SVM), Penalized Discriminant Analysis (PDA), dan Random Forest (RF). Penerapan 4 structuring element mengakibatkan adanya kompleksitas komputasional yang tinggi.

Penelitian ini bertujuan untuk menyederhanakan kompleksitas komputasional dengan menerapkan satu dari sembilan structuring element (SE) pada UHMT. Sehingga, setiap sudut tulang daun dapat terdeteksi dengan pemilihan SE yang tepat.

\section{Tinjauan Pustaka}

\subsection{Adaptive Thresholding}

Proses thresholding akan menghasilkan citra biner, yaitu citra yang memiliki dua nilai tingkat keabuan hitam dan putih. Secara umum proses thresholding citra grayscale untuk menghasilkan citra biner ditunjukkan pada persamaan 1.

$$
g(x, y)=\left\{\begin{array}{ll}
1 & \text { if } f(x, y) \geq T \\
0 & \text { if } f(x, y)<T
\end{array}\right\}
$$

Dimana $\mathrm{g}(\mathrm{x}, \mathrm{y})$ merupakan citra biner dari grayscale $\mathrm{f}(\mathrm{x}, \mathrm{y})$ dan $\mathrm{T}$ menunjukkan thresholding. Kualitas dari citra biner sangat tergantung dari nilai $\mathrm{T}$ yang digunakan. Salah satu jenis thresholding adalah adaptive thresholding. Pada adaptive thresholding dapat mengatasi citra yang memiliki intensitas bergradasi karena adanya bayangan dan cahaya. Hal tersebut mengakibatkan nilai thresholding yang sama dimungkinkan tidak memiliki manfaat pada seluruh bagian citra. Metode adaptive thresholding menentukan nilai threshold pada setiap bagian dari citra (Ahmad, 2005).

\subsection{Unconstrained Hit or Miss Transform (UHMT)}

UHMT digunakan pada citra abu-abu, untuk memisahkan bagian depan dan bagian belakang pada suatu citra (Larese, dkk, 2013). Metode ini digunakan pada proses segmentasi. Proses ekstraksi piksel dilakukan berdasarkan sifat ketetanggan. UHMT ditunjukkan pada persamaan 2. 
$\operatorname{UHMT}_{B}(Y)(y)=\max \left\{\varepsilon B_{f g}(Y)(y)-\delta B_{b g}(Y)(y), 0\right\}$,

Dimana, y = citra abu-abu dengan pixel y, B = gabungan $S E$. Hal tersebut digunakan untuk menghitung perbedaan antara erosi dan dilasi. Kondisi secara umum adalah erosi lebih besar daripada dilasi (Larese, dkk, 2013) Hasil UHMT yang diperoleh dibandingkan yaitu pada kondisi erosi lebih besar dari pada dilasi menggunakan operasi pengurangan. Sedangkan jika erosi lebih kecil atau sama dengan dilasi, nilainya adalah 0 .

Erosi merupakan operasi yang digunakan untuk menghapus piksel-piksel objek. Sehingga, ukuran objek dapat diperkecil. Sedangkah dilasi merupakan kebalikan dari erosi, yaitu penambahan piksel-piksel objek untuk memperbesar ukuran objek (Ahmad, 2005). Dilasi Y oleh B ditunjukkan pada persamaan 3.

$Y \oplus B=\{c \mid c=a+b, y \in Y, b \in B\}$

Sedangkan erosi Y oleh B ditunjukkan pada persamaan 4.

$Y \ominus B=\left\{c \mid(B)_{c} \subseteq Y\right\}$

Sehingga, dapat dikatakan citra sebagai hasil operasi erosi mengandung piksel-piksel, dimana SE ditranslasikan dengan piksel yang ada pada citra A.

\subsection{Local Binary Pattern (LBP)}

Local Binary Pattern (LBP) digunakan untuk mendeskripsikan pola-pola tekstur lokal pada citra dengan mode warna abu-abu. LBP diterapkan pada proses ektraksi fitur yang merupakan operasi citra yang mentransformasikan sebuah citra dalam menggambarkan kenampakan skala kecil dari citra tersebut.

Dalam representasi tekstur LBP, setiap pola direpresentasikan oleh sembilan elemen dengan $p_{\text {pusat }}$ menunjukkan nilai intensitas pada piksel pusat dan $p_{i}$ menunjukkan nilai piksel sekelilingnya. Nilai delapan ketetanggaan yang mengelilingi pusat piksel dapat dicirikan oleh nilai biner $d_{i}$ yang diperoleh menggunakan persamaan 5 .

$$
d= \begin{cases}1 & \text { if } \Delta p_{i} \geq 0 \\ 0 & \text { if } \Delta p_{i}<0\end{cases}
$$

Dengan nilai $\Delta p_{i}$ ditunjukkan pada persamaan 6 .

$$
\Delta p_{i}=p_{i}-p_{\text {pusat }}
$$

LBP membandingkan nilai biner pada piksel terhadap nilai pusat dari citra dengan 8 nilai piksel di sekelilingnya. Perbandingan tersebut dilakukan dengan cara mengurangi nilai piksel pada pusat citra dengan nilai piksel di sekelilingnya. Jika hasil yang diperoleh lebih dari atau sama dengan 0 , maka diberikan nilai 1 . Jika hasil yang diperoleh kurang dari 0 , maka diberikan nilai 0. Pengusunan delapan nilai biner tetangga dilakukan searah jarum jam atau sebaliknya. Kemudian dilakukan perubahan delapan nilai biner ke dalam nilai desimal. Tujuannya adalah untuk menggantikan nilai pada pusat citra (Ahonen, Hadid \& Pietik, 2006).

\subsection{Support Vector Machines (SVM)}

Menurut Prasetyo (2012), metode SVM (Support Vector Machine) merupakan teori pembelajaran statistic dan dapat memberikan hasil yang lebih baik dari pada metode yang lain. SVM dapat bekerja dengan baik pada data dengan berdimensi set tinggi. Selain itu, SVM menggunakan teknik kernel dan hanya sejumlah data yang terpilih yang berkontribusi untuk membangun model klasifikasi. Hal tersebut menjadi kelebihan SVM, karena tidak semua data latih akan dilihat untuk dilibatkan dalam setiap iterasi pelatihannya. Konsep dasar dari SVM 
yaitu membentuk hyperplane (maximal margin hyperplane). Cara menemukan hyperplane ditunjukkan pada gambar 1.

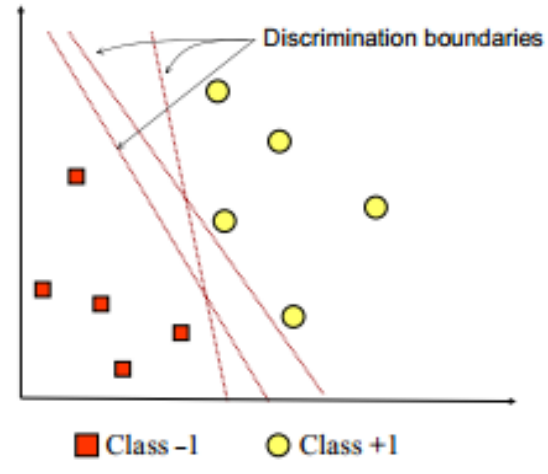

(a)

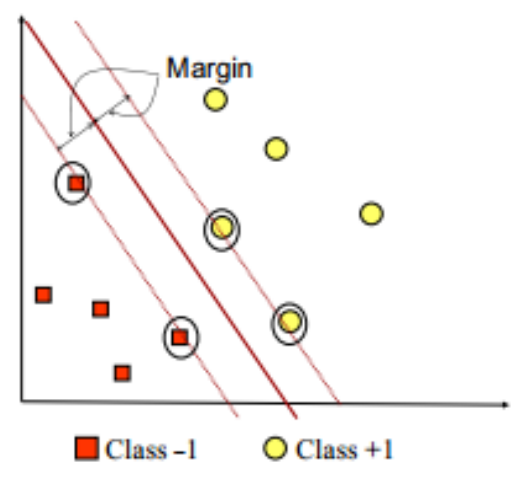

(b)

Gambar 1. (a) Decision boundary yang mungkin dan (b) Decision boundary dengan margin maksimal

Gambar 1 memperlihatkan beberapa pattern yang merupakan anggota dari dua buah kelas: +1 dan -1 . Pattern yang tergabung pada kelas -1 disimbolkan dengan warna merah (kotak), sedangkan pattern pada kelas +1 , disimbolkan dengan warna kuning (lingkaran). Problem klasifikasi dapat diterjemahkan dengan usaha menemukan hyperplane yang memisahkan antara kedua kelompok tersebut. Berbagai alternatif garis pemisah (discrimination boundaries) ditunjukkan pada gambar a.

Hyperplane pemisah terbaik antara kedua class dapat ditemukan dengan mengukur margin hyperplane tersebut dan mencari titik maksimalnya. Margin adalah jarak antara hyperplane tersebut dengan pattern terdekat dari masing-masing kelas. Pattern yang paling dekat ini disebut sebagai support vector. Garis tebal pada gambar b menunjukkan hyperplane yang terbaik, yaitu yang terletak tepat pada tengah-tengah kedua kelas, sedangkan titik merah dan kuning yang berada dalam lingkaran hitam adalah support vector.

\subsection{K-Fold Cross Validation}

K-Fold Cross Validation merupakan salah satu teknik untuk melakukan estimasi tingkat kesalahan pengujian pemrosesan citra digital. Menurut Fauzie (2010) cara kerja K-fold cross validation yaitu dengan mengelompokkan data latih dan data uji yang saling terpisah, kemudian melakukan proses pengujian yang diulang sebanyak $K$ kali.

Langkah dari $K$-fold cross validation (Pratiwi, 2010) antara lain: (1) Membagi data yang tersedia menjadi $K$ kelompok. (2) Setiap K dibuat sejumlah T himpunan data yang memuat semua data latih kecuali yang berada di kelompok ke-k. (3) Mengerjakan algoritma yang dimiliki dengan sejumlah $\mathrm{T}$ data latih. (4) Pengujian algoritma menggunakan data pada kelompok $K$ sebagai data uji. (5) Melakukan pencatatan hasil algoritma. Menurut Pratiwi (2010) keuntungan dari teknik $K$-fold cross validation yaitu menunjukkan bahwa semua elemen pada baris data digunakan untuk pelatihan sekaligus pengujian.

\section{Metodologi Penelitian}

Rancangan sistem klasifikasi jenis tanaman mangga gadung dan madu berdasarkan tulang daun ditunjukkan pada gambar 2. Berdasarkan gambar 2, ditunjukkan proses pengolahan citra pada daun untuk mendapatkan klasifikasi daun mangga madu dan gadung. Masukan citra berupa citra daun RGB, kemudian diolah menjadi citra abu-abu. Pada penelitian ini, konversi citra abu-abu menjadi citra biner dengan menggunakan adaptive thresholding. Tujuan pada tahap ini yaitu untuk mengetahui struktur tulang daun yang dianggap menjadi foreground. Bagian citra selain tulang daun dianggap sebagai background. 
Kemudian pada proses segmentasi menerapkan UHMT dengan sembilan SE untuk memperjelas struktur daun. Penggunaan LBP pada proses ekstraksi fitur yaitu untuk mengetahui pola fitur dari tulang daun, yang kemudian ukuran fitur dihitung menggunakan entropy. Kemudian pada proses yang terakhir, yaitu klasifikasi, nilai entropy fitur diproses menggunakan SVM. Pengujian dilakukan dengan menggunakan $K$-fold cross validation. Sehingga diperoleh tingkat akurasi klasifikasi dari mangga madu dan gadung.

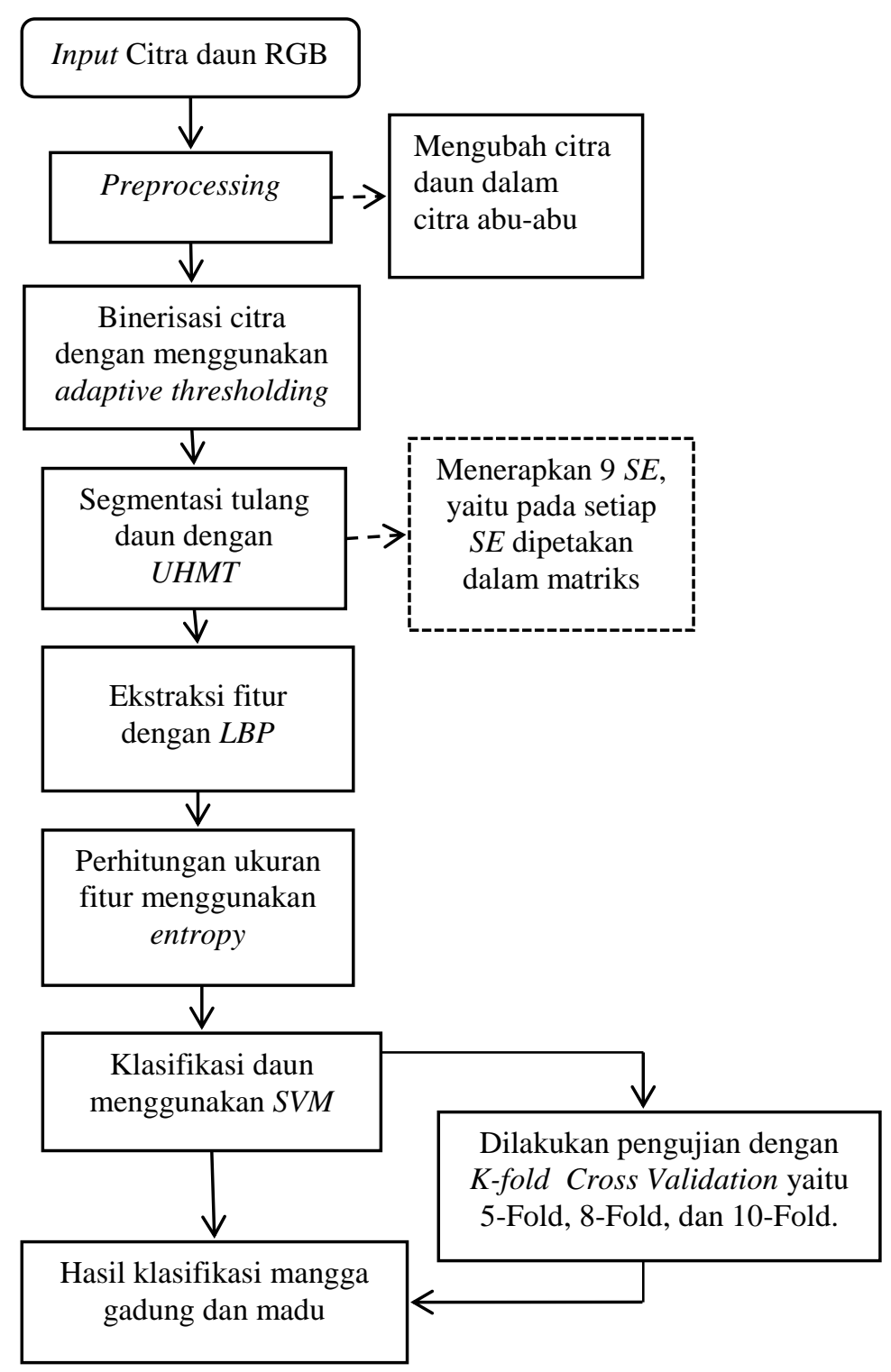

Gambar 2. Rancangan klasifikasi Jenis Tanaman Mangga Gadung dan Madu Berdasarkan Tulang Daun

\subsection{Dataset}

Data yang digunakan pada penelitian ini diambil menggunakan kamera DSLR Canon 1100D dengan kondisi dan waktu yang sama. Terdapat 400 citra daun yang masing-masing terdapat 200 citra daun mangga gadung dan 200 citra daun mangga madu, yang kemudian akan dipilih secara acak untuk menentukan citra yang sebagai data latih dan uji. Pada penelitian ini terdapat 320 citra untuk data latih dan 80 citra untuk data uji.

Data yang diperoleh kemudian diolah terlebih dahulu pada tahap preprocessing. Dalam tahap preprocessing, ada beberapa langkah yang dilakukan untuk kemudahan pemrosesan data 
pada tahap selanjutnya, yaitu proses segmentasi. Beberapa langkah yang dilakukan adalah (1) citra tersebut dirotasi untuk mendapatkan tampilan yang seragam, (2) citra yang diperoleh memiliki ukuran yang besar, sehingga citra diperkecil untuk mempercepat pemrosesan citra, dan (3) meningkatkan kontras yang dimiliki oleh citra dengan image enhancement.

\subsection{Proses Klasifikasi Daun Mangga Berdasarkan Tulang Daun}

Masukan citra daun RGB dilakukan preprosesing untuk meningkatkan kualitas pada citra yang kemudian dilakukan konversi citra biner menggunakan adaptive thresholding. Proses yang dilakukan pada tahap preprocessing sangat mempengaruhi kualitas citra pada tahap selanjutnya. Citra input yang berupa citra RGB, dikonversi dalam citra abu-abu. Citra abu-abu merupakan citra dengan warna abu-abu dengan variasi gradasi abu-abu. Kemudian dilakukan binerisasi citra, yaitu citra yang setiap pikselnya memiliki dua nilai kemungkinan, yaitu 0 dan 1 .

Proses segmentasi pada penelitian ini menggunakan UHMT dengan penggabungan struktur bagian depan dan belakang citra yang bertujuan untuk mendeteksi tulang daun dengan sembilan arah yang berbeda. Karena setiap tulang daun memiliki titik percabangan yang berbeda di berbagai arah. Sembilan SE ditunjukkan pada gambar 3.

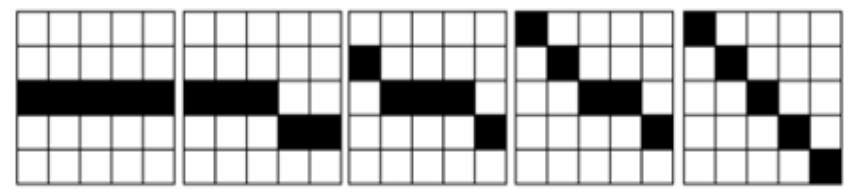

(a)

(b)

(c)

(d)

(e)

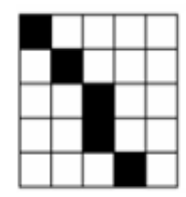

(f)

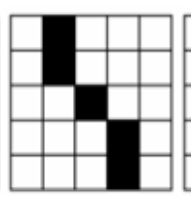

$(\mathrm{g})$

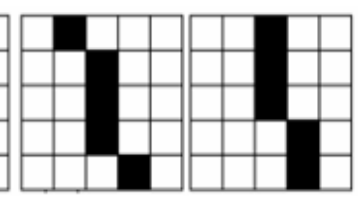

(h)

(i)

Gambar 3. Sembilan structuring element (a) structuring element 1 (b) structuring element 2 (c) structuring element 3 (d) structuring element 4 (e) structuring element 5 (f) structuring element 6 (g) structuring element 7 (h) structuring element 8 (i) structuring element 9

Setiap SE mendeteksi setiap piksel dari citra tulang daun. Adapun nilai letak piksel dari setiap SE, ditunjukkan pada tabel 1. Tabel 1 menunjukkan nilai setiap piksel dari SE dengan ukuran window $5 \times 5$. Setiap SE memiliki nilai piksel yang berbeda, tergantung pada bentuk SE yang digunakan. Piksel yang menunjukkan warna hitam memiliki nilai piksel yang sesuai dengan nilai yang ditunjukkan pada tabel 1 .

Tabel 1. Nilai piksel dari setiap SE

\begin{tabular}{ccccc}
\hline$(\mathrm{m}-2, \mathrm{n}-2)$ & $(\mathrm{m}-2, \mathrm{n}-1)$ & $(\mathrm{m}-2, \mathrm{n})$ & $(\mathrm{m}-2, \mathrm{n}+1)$ & $(\mathrm{m}-2, \mathrm{n}+2)$ \\
\hline$(\mathrm{m}-1, \mathrm{n}-2)$ & $(\mathrm{m}-1, \mathrm{n}-1)$ & $(\mathrm{m}-1, \mathrm{n})$ & $(\mathrm{m}-1, \mathrm{n}+1)$ & $(\mathrm{m}-1, \mathrm{n}+2)$ \\
\hline$(\mathrm{m}, \mathrm{n}-2)$ & $(\mathrm{m}, \mathrm{n}-1)$ & $(\mathrm{m}, \mathrm{n})$ & $(\mathrm{m}, \mathrm{n}+1)$ & $(\mathrm{m}, \mathrm{n}+2)$ \\
\hline$(\mathrm{m}+1, \mathrm{n}-2)$ & $(\mathrm{m}+1, \mathrm{n}-1)$ & $(\mathrm{m}+1, \mathrm{n})$ & $(\mathrm{m}+1, \mathrm{n}+1)$ & $(\mathrm{m}+1, \mathrm{n}+2)$ \\
\hline$(\mathrm{m}+2, \mathrm{n}-2)$ & $(\mathrm{m}+2, \mathrm{n}-1)$ & $(\mathrm{m}+2, \mathrm{n})$ & $(\mathrm{m}+2, \mathrm{n}+1)$ & $(\mathrm{m}+2, \mathrm{n}+2)$ \\
\hline
\end{tabular}

Kondisi yang digunakan pada sembilan SE pada penelitian ini adalah dengan dijalankan satu persatu pada setiap SE. Pseudocode untuk menggunakan sembilan SE ditunjukkan pada kode 1.

Kode 1. Pseudocode Sembilan Structuring Element

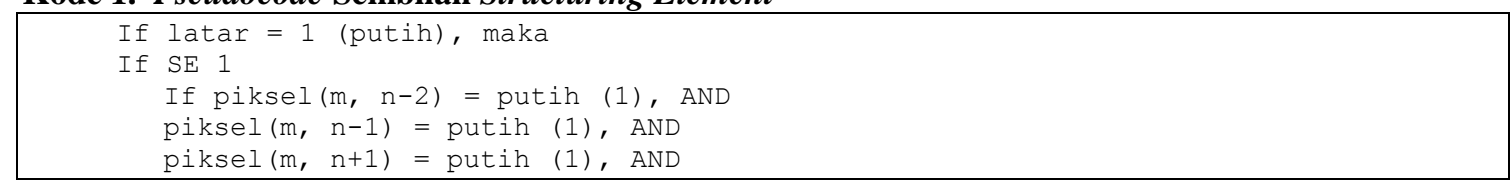




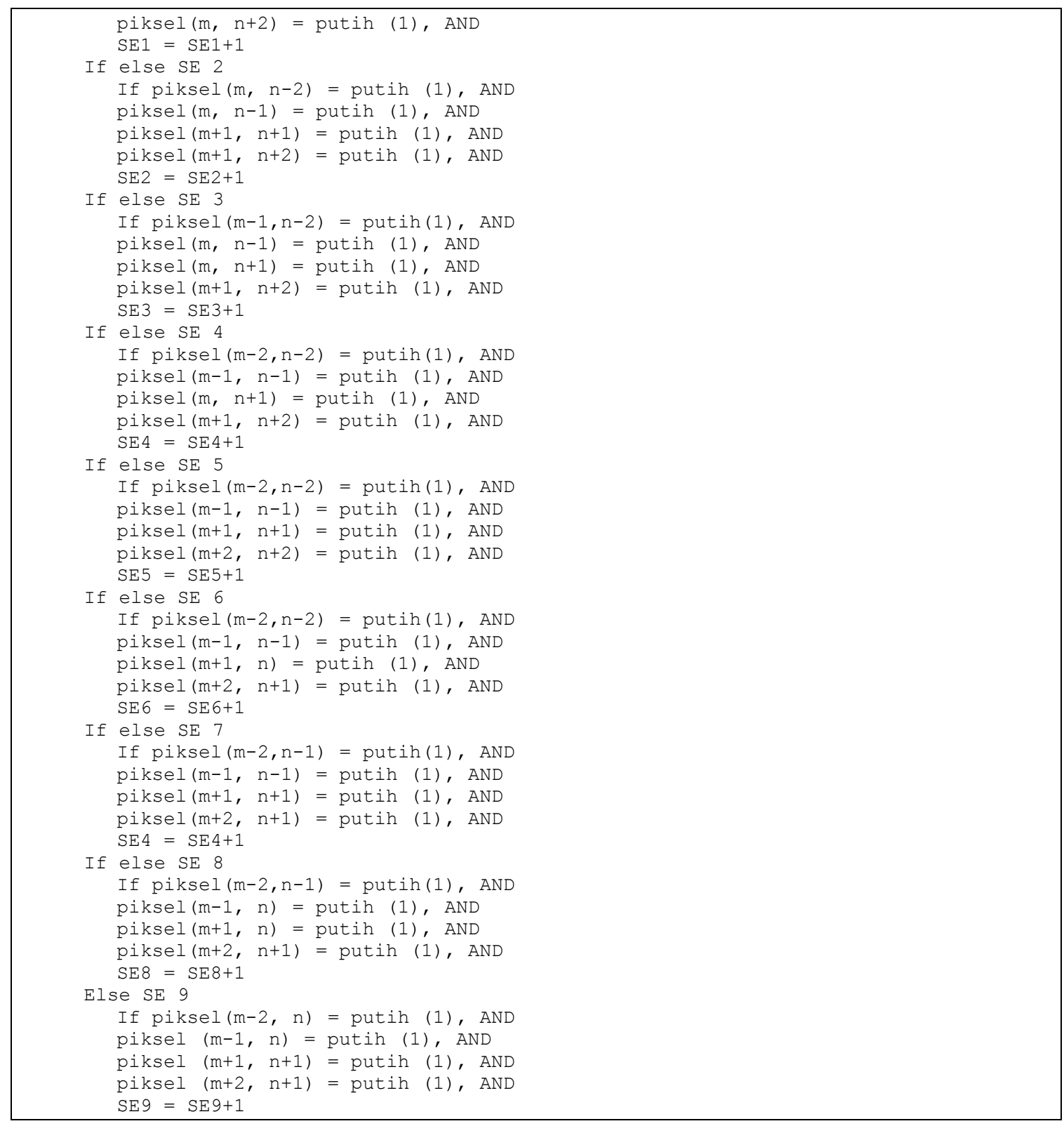

Ekstraksi fitur menggunakan LBP yang diusulkan pada penelitian ini digunakan untuk mengetahui pola dari tekstur tulang daun. Penerapan LBP dengan window $3 \times 3$ pada tekstur tulang daun ditunjukkan pada gambar 4.
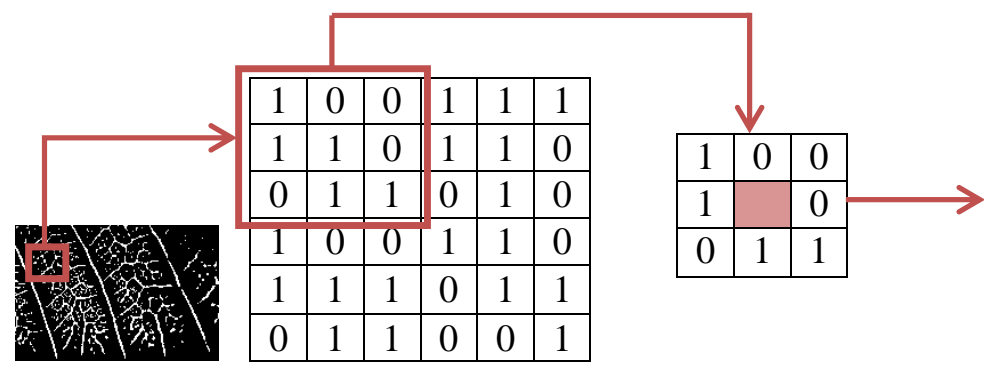

Diperoleh perhitungan biner, yaitu:

$10001011=139$

\section{Gambar 4. Penerapan LBP Pada Citra Daun Grayscale}


Langkah selanjutnya yaitu menghitung fitur dengan menggunakan entropy. Entropy menunjukkan ukuran yang tidak beraturan dari bentuk suatu citra. Persamaan yang digunakan untuk menghitung entropy ditunjukkan pada persamaan 7 .

$H=-\sum_{n} p\left(f_{n}\right)^{2} \log p\left(f_{n}\right)$

Di mana, $p\left(f_{n}\right)$ menunjukkan probabilitas kemunculan intensitas tersebut pada citra.

Setelah dilakukan perhitungan entropy, maka dilakukan klasifikasi menggunakan SVM dengan pengujian menggunakan $K$-fold cross validation. Akurasi dari 5-fold, 8 fold, dan 10-fold dibandingkan, kemudian dipilih nilai akurasi yang tertinggi.

\section{Pengujian dan Pembahasan}

Skenario uji coba dilakukan terhadap dataset yang terdiri dari 400 citra daun, yaitu 200 citra daun mangga berjenis gadung dan 200 citra daun mangga berjenis madu. Citra masukan berupa citra RGB. Pengambilan citra dilakukan pada sebagian area daun, dimana salah satu contoh pengambilan citra ditunjukkan pada gambar 5. Gambar 5 menunjukkan pengambilan citra daun pada sebagian area daun. Hal tersebut bertujuan untuk memperjelas tekstur tulang daun. Citra masukan yang berupa citra RGB dikonversi menjadi citra abu-abu. Konversi citra abu-abu ditunjukkan pada gambar 6.

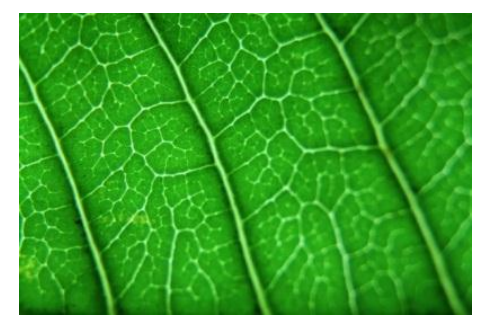

Gambar 5. Contoh Pengambilan Citra Daun

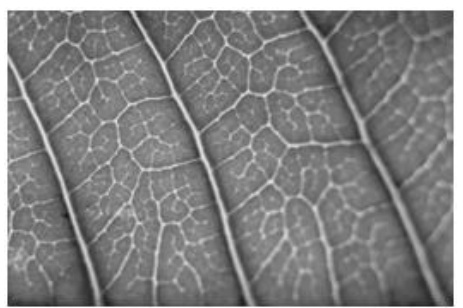

Gambar 6. Konversi citra RGB ke Citra Abu-abu

Pada penelitian ini, fitur yang dihitung adalah fitur tulang daun. Hasil citra abu-abu diubah ke dalam citra biner menggunakan adaptive thresholding. Adaptive thresholding digunakan untuk mengatasi citra yang dimungkinkan memiliki nilai threshold yang berbeda. Perbedaan nilai threshold dikarenakan adanya noise, misalnya cahaya dan bayangan. Adaptive thresholding digunakan untuk memisahkan antara foreground dan background. Pada penelitian ini foreground merupakan tulang daun yang direpresentasikan angka 1 dengan warna putih. Sedangkan, background merupakan area selain daun yang direpresentasikan angka 0 dengan warna hitam. Hasil binerisasi citra daun menggunakan adaptive thresholding ditunjukkan pada gambar 7.

Setelah dilakukan proses binerisasi, citra biner tersebut ditransformasi dengan UHMT untuk mendapatkan bentuk morfologi daun yang lebih jelas. Pada proses UHMT diterapkan sembilan SE, yaitu dengan memilih salah satu SE yang tepat untuk menampilkan bentuk morfologi tulang daun. Pemilihan dan pengaturan ukuran dan bentuk dari SE dapat digunakan untuk mengatur sensitivitas operasi morfologi terhadap bentuk yang spesifik pada citra daun. Pada penelitian ini, ukuran window SE yang digunakan adalah 5x5. Operasi morfologi yang digunakan adalah dilasi dan erosi. Dilasi digunakan sebagai operasi penambahan piksel pada batas objek citra daun, sedangkan erosi digunakan sebagai operasi pengurangan.piksel pada batas objek citra daun. Jumlah piksel yang ditambahkan maupun dikurangi dari batas objek citra daun tergantung pada ukuran dan bentuk SE yang digunakan. Pada umumnya, erosi lebih besar dari pada dilasi dalam proses UHMT. Namun, dalam studi kasus penelitian ini hasil dilasi lebih besar daripada hasil erosi. Sehingga, pengurangan antara dilasi terhadap erosi dilakukan. Salah satu hasil yang diperoleh dari proses segmentasi menggunakan UHMT dengan structuring element ditunjukkan pada gambar 8. 


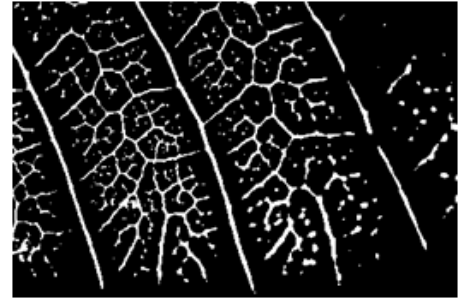

Gambar 7. Binerisasi Citra dengan Adaptive Thresholding

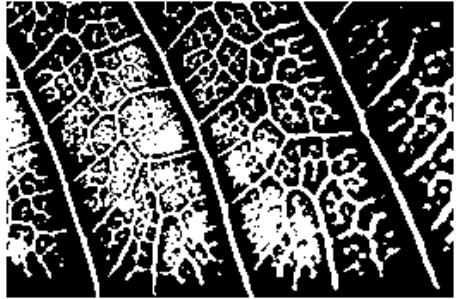

Gambar 8. Hasil UHMT dengan structuring element

Setelah didapatkan bentuk morfologi dari tulang daun, untuk mengekstraksi fitur tulang tersebut digunakan LBP. Penggunaan LBP dilakukan karena mampu membaca pola struktur biner secara rinci pada area lokal. Pemilihan metode LBP dikarenakan keluaran dari transformasi UHMT pada proses segmentasi merupakan citra biner. Dari proses tersebut, bisa dibedakan pola struktur tulang daun mangga gadung dan madu. Kemampuan entropy untuk merepresentasikan pola struktur atau tingkat keacakan nilai piksel membuat entropy layak digunakan sebagai fitur ukuran struktur tulang daun. Hasil entropy dari beberapa hasil data uji daun mangga gadung dan madu ditunjukkan pada tabel 2.

Tabel 2. Sebagian Hasil Data Uji Citra Mangga Gadung dan Madu

\begin{tabular}{ccc}
\hline Data Uji & Entropy & Kelas \\
\hline 1 & 1,116 & 1 \\
\hline 2 & 1,084 & 1 \\
\hline 3 & 1,044 & 1 \\
\hline 4 & 1,039 & 1 \\
\hline 5 & 1,062 & 1 \\
\hline 6 & 1,189 & 1 \\
\hline 7 & 1,098 & 1 \\
\hline 8 & 1,004 & 1 \\
\hline 9 & 1,090 & 1 \\
\hline 10 & 1,096 & 1 \\
\hline 11 & 2,076 & 2 \\
\hline 12 & 2,098 & 2 \\
\hline 13 & 1,917 & 2 \\
\hline 14 & 2,374 & 2 \\
\hline 15 & 2,218 & 2 \\
\hline 16 & 2,377 & 2 \\
\hline 17 & 2,277 & 2 \\
\hline 18 & 2,076 & 2 \\
\hline 19 & 2,098 & 2 \\
\hline 20 & 1,917 & 2 \\
\hline
\end{tabular}

Tabel 2 menunjukkan bahwa kelas 1 merepresentasikan kategori daun mangga gadung dan kelas 2 merepresentasikan kategori daun mangga madu. Secara umum hasil entropy dari ekstraksi fitur terhadap tulang daun mangga madu lebih besar dari pada hasil entropy ekstraksi fitur terhadap tulang daun mangga gadung. Hasil pengujian $K$-fold Cross Validation ditunjukkan pada tabel 3.

Tabel 3. Hasil Klasifikasi

\begin{tabular}{cc}
\hline K-fold Cross Validation & Akurasi (\%) \\
\hline 5 & 77.5 \\
8 & 75.5 \\
10 & 78.5 \\
\hline
\end{tabular}

Tabel 3 menunjukkan pengujian yang dilakukan dengan teknik $K$-fold Cross Validation, yaitu dengan membandingkan akurasi dari 5-fold cross validation, 8-fold cross validation, dan 10-fold cross validation. Hasil menunjukkan bahwa penggunaan 10-fold Cross Validation 
mencapai akurasi terbaik. Meskipun demikian, selisih akurasi antara percobaan satu dengan lainnya tidak memiliki perbedaan secara signifikan.

\section{Kesimpulan}

Fitur tulang daun mangga dijadikan acuan untuk membedakan kedua jenis tanaman tersebut, karena setiap jenis tanaman memiliki sudut tulang daun yang berbeda. Adanya keberagaman tekstur tulang daun, penelitian ini mengusulkan metode UHMT dengan sembilan SE pada proses segmentasi. Salah satu dari sembilan SE dipilih untuk mendapatkan tekstur tulang daun yang terbaik. Sehingga, dapat dipisahkan bagian tulang daun sebagai foreground dan daging daun sebagai background. Metode LBP digunakan pada proses ekstraksi fitur untuk menentukan pola tulang daun. Fitur yang dihasilkan dihitung dengan entropy yang kemudian diklasifikasikan menggunakan SVM. Pengujian menggunakan 10-fold cross validation dengan menunjukkan akurasi 78,5\%.

\section{Saran}

Pada penelitian selanjutnya dimungkinkan untuk dilakukan pemilihan SE secara otomatis pada UHMT, sehingga diperoleh hasil yang paling optimal.

\section{Referensi}

Ahmad, Usman. 2005. Pengolahan Citra Digital \& Teknik Pemrogramannya. Yogyakarta: Graha Ilmu.

Ahonen, Hadid, Abdenour. Pietik, Matti. 2006. Face Description with Local Binary Patterns. Application to Face Recognition. Vol. 28 no.12, pp. 2037-2041.

Fauzie, R. 2010. Pengenalan Citra Wajah Menggunakan Algoritma VFI5 dengan Praproses Principal Component Analysis. Bogor. Institut Pertanian Bogor.

$\mathrm{Fu}, \mathrm{H}$. Chi, Z. 2006. Combined thresholding and Neural Network Approach for Vein Pattern Extraction from Leaf Images. Image Signal Process. IEEE. Vol 153. No.6.

Jabal, Mohamad Faizal Ab, Hamid, Suhardi. Shuib, Salehuddin. Ahmad, Illiasak. 2013. Leaf Features Extraction and Recognition Approaches to Classify Plant. Journal of Computer Science. Vol 9. Hal 1295-1304.

Kadir, Nugroho. Susanto, Paulus. 2011. Leaf Classification Using Shape, Color, and Texture Features. International Journal of Computer Trends and Technology. ISSN: 2231-2803. Hal 225-230.

Larese, Monica G. Namiasa, Rafael. Craviottob, Roque M. Arangob, Miriam R. Gallob, Carina. Granittoa, Pablo M. 2013. Automatic Classification of Legumes Using Leaf Vein Image Features. Pattern Recognition. Vol 47. Hal 158-168.

Li, Yan, Chi, Cheru. 2006. Leaf Vein Extraction Using Independent Component Analysis. IEEE Conference on System, Man, and Cybernetics.

Lu, Hongfei, Jiang, Wu. Ghiassi, M. Lee, Sean. Nitin, Mantri. 2013. Classification of Camellia (Theaceae) Species using Leaf Architecture Variation and Pattern Recognition Technique. Plos One, Vol 7 Issue 1.

Prasetyo, Eko. 2012. Data Mining: Konsep dan Aplikasi Menggunakan MATLAB. Yogyakarta: Andi Offset.

Pratiwi. 2010. Pengembangan Model Pengenalan Wajah Dengan Jarak Euclid Pada Ruang Eigen Dengan 2DPCA. Bogor. Program Pascasarjana, Institut Pertanian Bogor.

Rashad, M Z. Desouky, B S el. Khawasik, Manal S. 2011. Plant Images Classification Based on Textural Features using Combined Classifier. International Journal of Computer Science \& Information Technology. Vol 3, No 4. Hal 93-100.

Zheng, Xiaodong. Wang Xiaojie. 2010. Leaf Vein Extraction Based on Gray-scale Morphology. International Journal of Image, Graphics and Signal Processing, Vol.2, No.2, pp.2531. 